\title{
СТИСЛИЙ ТЕКСТ ХХІ СТОРІЧЧЯ ЯК ПРОБЛЕМА ЛІНГВІСТИКИ ТА ПЕРЕКЛАДУ (НА МАТЕРІАЛІ РОСІЙСЬКОЇ ТА АНГЛІЙСЬКОЇ МОВ)
}

\section{Панченко О. І., Шевчик К. Ю.}

\section{ВСТУП}

Обсяг інформації, накопиченої людством, величезний і постійно збільшується. Для ії засвоєння, збереження і передачі користувачам так чи так доводиться вдаватися до стиснення текстів. Актуальність дослідження стислого тексту (СТ) зумовлена тим, що СТ, будучи поширеним у різних сферах людської діяльності способом спілкування, $\epsilon$ своєрідним явищем зі своїми стійкими параметрами i чіткою прагматичною спрямованістю як у статиці, так і в динаміці. Багато вчених визнають той факт, що людська мова та мовлення пов'язані 3 фактором підсвідомої економії зусиль, що дія закону економії $\epsilon$ незаперечним, постійно діючим у мові чинником. Принципи мовної економії розглядали Ш. Баллі, У. Дайвер, А. Мартіне, О. Есперсен, Р. Будагов, Н. Пащенко та ін. Але бурхливий розвиток усіх сфер будьякої мови потребує осучаснення можливостей досягнення мовної економії. Такий вид текстів, як стислі мовні твори, отримує в наш час новий імпульс у своєму розвитку; ці тексти змінюються перш за все 3 тієї причини, що в основі актів комунікації, засобом їх практичного здійснення є мова, що відображає дійсність, яка сама перебуває в постійному русі.

Метою нашого дослідження $є$ аналіз сучасного стислого тексту, засобів його стиснення та особливостей перекладу з російської мови англійською та навпаки. Досягнення поставленої мети передбачає розв'язання таких завдань: 1) проаналізувати наявні погляди на поняття «стислий текст»; 2) визначити засоби досягнення стислості тексту на різних мовних рівнях; 3) подати низку рекомендацій щодо можливостей перекладу СТ. Об'єктом дослідження є російськомовні та англомовні стислі тексти різних стилів та жанрів. Предмет дослідження - структурно-семантичні та функційно-прагматичні особливості СТ. Матеріалом для дослідження стали 500 текстів (250 російською мовою та 250 англійською мовою) різних жанрів науково-технічного, офіційно-ділового, газетно-публіцистичного (інтернет-тексти включно) та художнього стилів. 
Характер об'єкта, мета, завдання та загальний напрям дослідження зумовили використання відповідних методів лінгвістичного аналізу, основними $з$ яких $є$ описовий метод $з$ усім комплексом його прийомів, який припускає послідовний опис, систематизацію і класифікацію СТ у різних жанрах, метод кількісних підрахунків для аналізу кількісних характеристик лінгвістичних одиниць, які використовуються в СТ, метод суцільної вибірки досліджуваних одиниць, порівняльностилістичний метод для аналізу функціонування різних текстових жанрів.

Практичне значення дослідження. Зібраний i проаналізований матеріал може бути використаний для лінгвістичного аналізу текстів, для вивчення таких розділів мовознавства, як «Стилістика», «Лінгвістика тексту», а також для підготовки спеціальних курсів, пов'язаних із проблемами текстології, у тому числі й порівняльної, під час написання студентами кваліфікаційних і курсових робіт.

\section{1. Стислий текст як мовна універсалія}

\section{1. Визначення стислого тексту та його типів}

Ми визначаємо стислий текст як повідомлення, об'єктивоване подібно до будь-якого іншого тексту в письмовій формі, побудоване шляхом скорочення повного тексту або спочатку створене як коротке, призначене за необхідності для подальшого розгортання в більший текст ${ }^{1}$. СТ має більшу інформативну насиченість порівняно 3 первинним повним варіантом, яка досягається різноманітними обов'язковими і факультативними засобами всіх рівнів мови.

У лінгвістичній літературі представлено різні класифікації СТ. На нашу думку, $є$ два основні різновиди СТ: первинний стислий текст, що формується до створення повного варіанту, і вторинний стислий текст, який $\epsilon$ результатом переробки відповідного розгорнутого тексту. Первинний текст може потенційно розгортатися (словникова стаття, СМС-повідомлення) або необхідно розгортатися (проспект видання, план твору). Потенційно розгорнутий текст може бути незалежним, тобто зрозумілим без контексту i ситуації, ситуативно або контекстуально залежним або спиратися на екстралінгвістичну основу (підпис до малюнка). Необхідно розгорнутий текст може бути підготовлений для публікації і існувати самостійно (тези наукового повідомлення) або бути допоміжною ланкою під час побудови повного варіанту (план виступу). Своєю чергою вторинний СТ може існувати як

1 Панченко Е.И. Лингвистика сжатого текста (на материале современного русского языка) : дисс. ... д-ра филол. н. : 10.02 .02 «Русский язык». Днепропетровск, 1998. C. 15. 
невід'ємна складова частина повного тексту (план книги, формула винаходу) або являти собою окремий твір (реферат, анотація). 3 формальної точки зору стислі тексти можна розділити на нормовані стислі і форсовано стислі, тобто складені 3 порушенням будь-яких наявних норм сучасної літературної мови. Прикладом першого типу можуть бути тези наукового повідомлення, другого - телеграма або словникова стаття.

Стислі тексти мають комплекс факультативних ознак як у плані вираження, так і в плані змісту. В них здійснюється кількісне скорочення завдяки застосуванню різноманітних графічних скорочень, умовних позначень, елімінації зайвих слів, еліпсу допоміжних лексикосинтаксичних одиниць. Якісні перетворення в стислих текстах виражаються в зміні співвідношення частин мови, насамперед за рахунок нівелювання службових слів, інформативно насичені форми непрямих відмінків витісняють форми називного відмінка; загалом переважають більш прості за складом і значенням граматичні категорії. Створення особливого комунікативного феномена - стислого тексту можна вважати проявом творчої мовленнєвої діяльності суб'єкта.

\section{2. Економія та компресія як основа створення стислого тексту}

У природній мові надмірність, як правило, виступає в діалектичній єдності 3 протилежним ій явищем - мовною економією. Мовна економія отримуе різноманітне інтерпретування в наявних лінгвістичних роботах. Дослідження поняття економії в мові та мовленні має тривалу історію. Його початок належить до XVII сторіччя i пов'язаний 3 іменами Р. Декарта, П. Пассі, Г. Пауля, Г. Суіта, О. Есперсена та інших авторів. Проблемам інформативної насиченості, надмірності й економії в мові та мовленні присвячені, крім згаданих вище, роботи багатьох вітчизняних і зарубіжних лінгвістів, серед яких слід назвати Р. Будагова, Н. Лебедєву, Г. Пана, Н. Пашенко і багатьох інших. На думку О. Есперсена, мова вважається економною в таких випадках: коли одна і та ж форма виражає різні відносини; коли мова прагне до скорочення форм, зокрема, в разі вживання форми однини дієслова замість форми множини; коли допустима супресія, тобто те, що мовець не говорить, хоча міг би сказати; коли під час проголошення певних звуків економляться м'язові зусилля² .

Проблемами економії в мові та мовленні займалися I.О. Бодуен де Куртене, О. Пєшковський, О. Ахманова й інші автори. О. Ахманова визначає лінгвістичну економію як «прагнення мовця економити зусилля у користуванні промовою» і розглядає їі однією з причин зміни

2 Jespersen O. A Modern English Grammar on Historical Principles. Copenhagen, 1942. 1120 p. DOI: https://doi.org/10.4324/9780203715963. 
мови, особливо фонетичної зміни ${ }^{3}$ Взагалі необхідно відзначити, що явище економії найбільш повно вивчено саме у фонології. Економія мовних засобів набуває все більшого значення у зв'язку з технічними проблемами, що зумовлене екстралінгвістичною необхідністю передачі більшого обсягу інформації в тих же параметрах. Мовна економія має велике значення з точки зору технічних умов комунікації, i, крім того, психологи звертають увагу на те, що стислий текст сприймається швидше, точніше і запам'ятовується в більшому обсязі. О. Леонтьєв пише, що тільки той текст можна вважати справді зрозумілим, загальний сенс якого можна виразити в якій завгодно стислій формі ${ }^{4}$.

Вплив тенденції до економії та наявність компресії стають помітними практично в кожному функційному стилі сучасної літературної мови. На думку К. Мальченко, причиною компресії є таке: «Так или иначе понятие избыточности ассоциируют с различного рода повторениями, тавтологией... В связи с убыстряющимся темпом жизни становятся понятными поиски экономных языковых форм, облегчающих процесс коммуникации. Эта сложившаяся тенденция и предопределяет отрицательное отношение ко всему, что признается избыточным» 5 .

Г. Риш аналізує прояви компресії у таких іï аспектах, як: мовна компресія як засіб створення номінативних одиниць; складні слова, еквівалентні реченню; скорочені слова/усічені слова, еквівалентні слову або словосполученню; субстантивований прикметник, який абсорбує певне слово; заміна підрядного речення субстантивованим прикметником; заміна придаткового речення інфінітивною групою; синтаксичне скорочення, або так званий винос загального члена за дужку; еліпс дієслова-зв'язки; односкладні речення вигукового характеру; модальне слово як еквівалент речення ${ }^{6}$ тощо. Усі перелічені види та засоби компресії знаходять втілення у великій палітрі жанрів СТ.

\section{3. Жанрове різноманіття стислого тексту XXI ст.}

У дослідженнях сучасних лінгвістів велика увага приділяється тим різновидам творів науково-технічного, офіційно-ділового, газетнопубліцистичного та певною мірою художнього стилю, які характеризуються значним ступенем економії мовних засобів.

3 Ахманова О.С. Словарь лингвистических терминов. Москва: УРСС : Едиториал УРСС, 2004. С. 219.

4 Леонтьев А.А. Высказывание как предмет лингвистики и теории коммуникации. Синтаксис текста. Москва, 1979. С. 29.

5 Мальченко Л.А. К вопросу о компрессии и избыточности разговорной речи. Теория и практика лингвистического описания речи. Горький, 1976. Вып. 7. С. 38.

${ }^{6}$ Риш Г.А. К понятию компрессии в языке. Труды Самарского университета. Вопросы семантики индоевропейских языков. 1973. Вып. 24. С. 44-45. 
Так, у роботах М. Васильєвої та Е. Закгейм, Б. Дюндіка, І. Інфантової, В. Кобкова, Т. Ковальчук, В. Миронової, І. Севбо, Е. Скороходько, В. Соловйова, К. Сухенко і низки інших авторів розглядаються композиційні та лінгвістичні особливості різних зразків СТ науковотехнічного стилю.

За останні двадцять років у системі стислих текстів відбулися значні зміни. За нашими спостереженнями, основними напрямами змін можна вважати такі як:

- розширення і зміна номенклатури стислих текстів;

- зміна прагматичного вектора використання зазначеного типу текстів;

- зміни в лексичному наповненні СТ і їх синтаксичній структурі.

У роботі $^{7}$ представлено детально підібрану номенклатуру стислого тексту у всіх функційних стилях сучасної російської мови. За нашими спостереженнями, у цій номенклатурі в наявності такі зміни: в науковотехнічному стилі зберегли своє значення i навіть посилили його завдяки можливостям електронного їх подання словникові статті, анотації, реферати, написи і підписи до малюнків, інструкції, таблиці, тези повідомлень. У зв'язку з розширенням сфер використання комп'ютерних технологій усе більшого поширення набуває лінгвістичний супровід програм.

Поява Інтернету призвела до того, що процес забезпечення людини інформацією прискорився і розширився. Новими різновидами СТ, що з'явилися останніми роками, можна вважати дайджест, форум, онлайнову статтю. Стислі інформаційні тексти стали невід'ємною частиною телевізійного простору, де пріоритетне значення має «свіжа», актуальна інформація, яка постійно оновлюється. Серед них особливе місце посідають новинні тексти, що подаються в рухомому рядку виокремленій стрічці на закріпленому полі телевізійного екрана, яка плавно рухається у відповідному напрямку ${ }^{8}$.

В офіційно-діловому стилі змінилися способи організації спілкування, що призвело до зміни жанрового подання цього стилю. Практично пішли в минуле телеграми, все ширше використовуються повідомлення, передані по факсу, електронні листи, замовлення товарів через Інтернет; з'явився і поширився новий жанр - СМС-повідомлення, які мають власну символіку, лексику, структуру.

7 Панченко Е.И. Лингвистика сжатого текста (на материале современного русского языка) : дисс. ... д-ра филол. н. : 10.02 .02 «Русский язык». Днепропетровск, 1998.

${ }^{8}$ Тріщук О. Робота редактора над рухомим рядком. Вісник Книжкової палати. 2016. № 2. C. 7-10. 
Жанрова система СТ у художньому стилі практично не змінилася, можливо, тут варто говорити лише про широке проникнення в нього рекламних текстів, зокрема, слогана.

Аналізуючи дослідження останніх років, присвячені проблемам стиснення тексту, слід зазначити їх поворот у бік когнітивістики, тобто стислий текст стає цікавий вченим не 3 позиції його структури, а 3 точки зору його здатності організувати когнітивну діяльність людини.

\section{2. Засоби стиснення тексту в російській та англійській мовах}

\section{1. Компресія на графемному рівні}

Як відомо, компресія може проявлятися в стислих текстах на різних рівнях. На графемному рівні компресія тексту здійснюється у формі скорочення або вилучення певних графем. С випадки використання цього засобу компресії практично в усіх жанрах СТ, наприклад:

- загальноприйняті буквені скорочення, до яких можна уналежнити скорочення типу «и т. д.» (и так далее), «т. к.» (так как), «Кг» (килограмм), «Км» (километр), «в.» (век), «вв.» (века), «Г.» (год) та деякі інші, наприклад:

Гидромолот на базе Экскаватора-погрузчика JCB-3CX. Стоимость

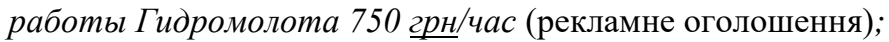

Кормушки рыбацкие. Кормушка весом 45 ㄹ, длина 71 мм, иирина 43 ․‥ Кормушка весом 30 ㄹ, длина 55 ㅆ. оголошення).

В англійській мові прикладами таких скорочень можна назвати загальноприйняті скорочення сторін світу $(S, N, S E)$, вимірювань $(f t, i n)$ та ін., які утім можуть мати й інше значення, наприклад:

Ft. mean "featuring" for short. Like for the example you gave, Jay Z will be singing the song, and Linkin Park will have a little segment/part in it. It can be during the song, or just one part. You hear a TON of people have a little rap section in the song, so that's why you see a lot of "feat".

$\mathrm{y}$ жанрах 3 форсованою компресією наявні специфічні буквені скорочення, типові, наприклад, для словників: $c f$. (confer = compare), $S$ - spoken, $W-$ written, pp (past participle or pages) тощо.

Графічні скорочення також не можна вважати цілком однорідними 3 точки зору частин, що підлягають скороченню. Взагалі виділяють такі їх різновиди:

1) скорочуються всі літери слова, окрім першої:

$v$-verb, $n$-noun; $C$ - countable noun, $U$ - uncountable noun;

2) скорочується середина та кінець слова, а лишаються перші 2-3 літери:

usu - usually, esp - especially; obs. - obsolete, sl - slang; unc. uncertain. 
Скорочення такого типу можна вважати більш автономними, оскільки більшість з них може бути зрозуміла навіть поза контекстом.

3) ненормативні скорочення, коли «випускаються» лише деякі літери із середини слова:

fml-formal, infml-informal; Gmc-Germanic; bk-book, ft-feet.

4) скорочуються частини складного слова або фрази:

$s b$ - somebody, sth - something.

Зазначимо, що у багатьох словниках основні скорочення, що вживаються в них, наводяться в спеціальному розділі, котрий зазвичай носить назву «Список основних скорочень» або «Скорочення та символи», що значно полегшує роботу читача зі словником. До таких списків, як правило, включаються скорочення, що позначають граматичні (pp, Gp, v, adj., fem, Vnn), стилістичні (arch., fig, joc, sl) особливості вживання слова, джерело походження або варіант мови, де вживається слово (AmE, BrE, NZ - New Zealand, MFr - Middle French) та багато інших.

У такому поширеному жанрі СТ, як газетні повідомлення, скорочення мають дещо інший характер. Для англомовних коротких газетних повідомлень $є$ типовим широке використання префіксів до імен: $M r, M s, M r s, J r$ :

Justice Dept. confirms Trump Jr. and McGahn did not testify to Mueller grand jury (https://www.politico.com/news/donald-trump-jr/2).

Варто звернути увагу також на скорочення першої частини складних географічних назв у досліджуваних нами стислих текстах, наприклад:

N. Korea Releases Russian Cargo Ship as Two-Week Ordeal Ends Peacefully (MN No.3, 2006).

На графемному рівні СТ також притаманне специфічне використання розділових знаків: знаки пунктуації можуть грати певну роль у процесі побудови стислого тексту, зокрема слід відзначити роль дужок, двокрапки, дефіса, трьох крапок, наприклад:

It's an exciting time to be a designer in technology (See also John Maeda's recent report on this topic.) We are in the middle of a sweeping sea change, and I can't wait to see where things are 10 years from now. Looking ahead and taking some lessons from more established cousin fields like industrial design, graphic design, and fashion, here my my predictions where design in Silicon Valley will be in the next 10 years:

1. Designers will be expected to craft end-to-end experiences rather than just interfaces; product and services that can be contained entirely within the screen will be outliers rather than the norm.

Дужки застосовуються 3 метою виділення певної інформації задля привернення до неї уваги читача. У дужках у словниках зокрема 
наводиться транскрипція слова flay /flei/ $v ; \boldsymbol{o b} \cdot \mathbf{t a i} \cdot \boldsymbol{n a} \cdot \boldsymbol{b l e} / \partial b^{\prime} t e i n \partial b \partial l /$ adj; інформація етимологічного характеру bur.glar $n[<O f r$. $<$ Anglo-L. $<$ LL. burgulator; ? < Gmc. burg, a dwelling + L. latro, robber]; інформація щодо граматичних, стилістичних та ін. особливостей вживання слова у мові; інформація про варіанти слова та його словоформи або похідні.

У словниковій дефініції широко використовуються також різноманітні символи. Так, наприклад, у разі наведення інформації щодо етимології слова застосовуються такі знаки:

< - для позначення джерела походження та попередньої форми такого слова ((derived) from);

? - вказує на те, що джерело походження слова лишається не визначеним, або існують сумніви щодо нього, оскільки не існує прямих доказів (uncertain);

+ - для вказівки на те, що слово є складним і складається з частин, що поєднані знаком «плюс».

Широкого використання також отримує у словниковій дефініції й знак «-» (дефіс), котрий вживається з метою скорочення повної форми слова для зазначення особливих форм слова або його похідних. e.g. liquify v (pt, pp-fied); specialize, -ise v; tatty adj (-ier, -iest).У цьому разі дефіс замінює спільну частину слів, а після нього наводиться лише диферінціююча частина.

Важливу роль пунктуаційні знаки відіграють у коротких газетних повідомленнях. Дужки в коротких газетних інформаційних повідомленнях виконують такі функції, як:

1) позначення джерела надходження інформації - вказівка певного інформаційного бюро, наприклад:

MOSCOW, May 2 (Interfax) - The prosecutor has asked the court to find the defendants in the murder case of editor of the Russian edition of Forbes magazine Paul Klebnikov guilty. "The prosecutor believes that the guilt of the defendants has been fully proven and asked to find them guilty on all charges". Ruslan Koblev, lawyer for one of the defendants, told Interfax on Tuesday. (MN)

2) позначення слів, які уточнюють, пояснюють яку-небудь інформацію, надану раніше, наприклад:

MOSCOW, April 21 (Reuters) - A major earthquake struck the Kamchatka peninsula in Russia's Far East on Friday, damaging some buildings and slightly injuring a few people in the remote region, the Emergencies Ministry said. The 7.7 magnitude tremor occurred at 12:25 p.m. local time (2325 GMT Thursday) roughly 7.8 miles $(12.6 \mathrm{~km})$ underground, the U.S. Geological Survey said on its Web site. 
Двокрапка використовується 3 метою виділення узагальнюючого слова в заголовках, після якого необхідне пояснення, наприклад:

Yushchenko aide: Ukraine disappointed with CIS (The Kyiv Post, May 2006);

Second Opinion: Sorting Out Pills to Reduce Breast Cancer Risk (NYT, January 2006).

Також двокрапка використовується у заголовках для виділення рубрики, до якої належить стаття, наприклад:

World Briefing: Asia, Americas, Middle East, Africa, Europe (NYT, May 2006);

The World: How Hamas Rose From Wild Card to Power (NYT, April 2006).

У заголовках, коротких інформаційних повідомленнях двокрапкою позначається місце події:

RUSSIA: New Rescue Vessel In The Works (NT, December 2005);

UZBEKISTAN: 37 Jailed In Andijon Uprising (NT, December 2005).

Іноді замість двокрапки, коли місце події не позначається в заголовку інформаційного повідомлення, воно виділяється комою на самому початку тексту:

MOSCOW, April 21 (Reuters) - Two students died on Friday in a fire at Moscow State University, one of the Russian capital's most imposing landmarks. The Emergencies Ministry said four others were injured in the blaze, which broke out in the early hours of the morning at the building, one of the Stalin-era skyscrapers that loom over Moscow. (MN, 2006).

Внаслідок нашого аналізу ми можемо зробити висновок, що розділові знаки $є$ певним засобом економії, тому що заміняють більш об’ємні лексичні одиниці або цілі речення.

Сполучення різних шрифтів, наявність абзаців, рубрикація, нумерація, умовні значки відіграють важливу роль у компресії текстів, тому що сприяють швидкому й цілісному сприйняттю інформації читачем. Так, для коротких інформаційних повідомлень характерна компактність, вони зводяться до одного абзацу, що є невід'ємною вимогою їхнього визначення:

\section{Forbes Lists 100 Richest Russians}

MOSCOW, April 20 (Reuters). The 100 richest Russians have assets worth $\$ 248$ billion or more than a quarter of Russia's nominal gross domestic product, according to the Russian version of Forbes magazine. The five richest members of the list - Abramovich, Alekperov, Vladimir Lisin, owner of steel maker NLMK, Mikhail Fridman, owner of Alfa Group, and Viktor Vekselberg, a shareholder in TNK-BP - have a total wealth of $\$ 62.8$ billion. 
Також у вищенаведеному прикладі ми бачимо, що заголовок і місце події виділені жирним шрифтом, цей метод практикується в газетах, тому що прописні літери й жирний шрифт допомагають сконцентрувати увагу читача на інформації, а також допомагають йому орієнтуватися у величезному обсязі газетної інформації - легко вибрати замітку на тему, що його цікавить.

\section{2. Граматичний рівень стиснення тексту}

Специфіка лінгвістичної побудови різних видів текстів значною мірою проявляється на їх граматичному рівні (морфологічному i синтаксичному). До морфологічних особливостей стислих текстів можна уналежнити: 1) співвідношення використовуваних у них частин мови; 2) особливості функціонування найбільш значущих частин мови i ï категорій. Аналіз складу мовних одиниць стислих текстів, проведений лінгвістами 3 точки зору приналежності їх до тих чи тих частин мови, свідчить, що практично у всіх стислих текстах найістотнішу роль відіграють іменники, наприклад.

Lockdown to continue in COVID-19 hotspots, hints PM Modi. COVID-19 hotspots will not get any relief from the lockdown after May 3, PM Modi hinted at a meeting with Chief Ministers today. The nationwide lockdown, imposed to contain coronavirus spread, will end on the aforementioned date, but the curbs will remain in place in areas where the infections haven't been controlled. Of the nine CMs, five said the lockdown must be lifted, while others contradicted (50\% знаменних слів є іменниками, 30\% - дієслова).

Механізм стиснення тексту, ймовірно, найбільш яскраво i різноманітно виявляється на синтаксичному рівні. Досліджуючи стислі тексти на цьому рівні, слід звернути увагу на розмір і основні типи речень у стислих текстах, ступінь їх поширеності, особливості функціонування членів речення та деякі інші характеристики. За даними деяких учених, більшість стислих текстів складається із складносурядного безсполучникового речення, що включає від двох до п'яти частин, наприклад:

Мобильное рабство. Яна Брагина беседует с Дэниелом Сибергом, официальным представителем Google и футурологом. Речь, как это ни выглядит странным, идёт о новой реальности, с которой столкнулись люди с приходом в нашу жизнь электронных гаджетов $u$ особенно смартфонов. Плюсы новых технологий в общем понятны, но при этом люди перестают общаться глаза в глаза. Что нас ждёт дальще и что необходимо предпринять? Журнал «Вокруг света» http://www.vokrugsveta.ru.

Типовий текст дайджесту статті в науково-популярному виданні складається із 5 синтаксичних одиниць, перша 3 яких являє собою заголовок, виражений словосполученням. Із 4 речень у тексті одне $\epsilon$ 
простим, одне складнопідрядним, два складносурядні, тобто $75 \%$ одиниць є складними.

Кількість граматичних конструкцій та зворотів зростає 3 підвищенням складності тексту, особливо в англомовному СТ. У найбільш інтенсивно згорнутих текстах відзначаються різні види інфінітивних зворотів, найбільше поширення серед яких має називний з інфінітивом; а також різні види дієприкметникових зворотів, особливо означальний та обставинний, які замінюють відповідні підрядні речення. Нерідко такі звороти зазнають впливу еліпсу, що сприяє ще більшій економії, а часто викликає переосмислення традиційних структур. Так, у результаті втрати дієслова-зв'язки в іменному інфінітивному звороті він набуває форми граматичного омоніму конструкції Participle II + інфінітив, яка зазвичай виконує функцію означення, але зберігає своє значення.

Наведемо приклад:

Movements and habits said to resemble Calandra; Known to attack sickly or injured stock and even donkey; Observed to raise crown feathers while pressing beak down on breast.

Лінгвістична компресія також проявляється в англійській мові у вилученні окремих службових частин мови та допоміжних слів. Серед частин мови, що підлягають елімінації, можна назвати прийменники, сполучники, допоміжні дієслова, частку to перед інфінітивом та інші. Поширеним $є$ вилучення сполучників and та or між однорідними членами речення під час переліку відповідних понять, оскільки вони можуть бути легко замінені безсполучниковим зв'язком або спеціальним графічним символом без втрати свого значення.

Obesity Tied to Higher Cancer Rates in Younger People.

У наведеному прикладі вилучено допоміжні дієслова (to be, to have), але значення можна зрозуміти і без них. Відсутність допоміжних засобів значно не впливає на семантичне значення речення, тоді як синтаксична структура зазнає змін.

\section{3. Лексико-семантичний рівень стиснення тексту}

На лексичному рівні лінгвістична компресія проявляється здебільшого у вживанні більш коротких синонімів. Так, прийняті в офіційно-діловій мові словосполучення типу to make a decision, to make a suggestion дуже часто у компресованому тексті замінюються на простіші форми to decide, to suggest, що мають те ж саме семантичне навантаження, хоч дещо й відрізняються в плані стилістичного забарвлення.

Останніми роками надзвичайно поширеними стали особливі лексичні одиниці в інтернет-мові, що охоплює розмовну мову, мову 
співзвуччя, піктограми (смайлики) та абревіатури. Назви деяких цифр i букв однакові зі словами, але їх набагато простіше і швидше написати:

to - 2, 2All-To All- всім; for -4, 4u = for you - для тебе, B4-before (до); ate -8, L8r-Later-niзніше; than -10, 10Q = Thank You (сnасибi).

Семантичний бік $\epsilon$ також важливим показником будь-якого стислого тексту. Еліпс тематичної частини повідомлення в стислих текстах посідає значно помітніше місце в кількісному плані порівняно 3 розгорнутим варіантом. У разі стиснення початкового варіанту повного тексту має місце зворотний процес, тобто перш за все скорочення тематичної частини повідомлення, що $\epsilon$ необхідною передумовою створення інформативного тексту. Наведемо приклад.

25-летний Антон умер, съев чужую сумку.

Прочитавши такий заголовок, мимоволі зацікавлений читач уявляє собі молоду людину, яка з незрозумілих причин харчується неїстівними предметами. Однак компресований елемент, заповнений у подальшому тексті, докорінно змінює його зміст:

В зоопарке немецкого города Штутгарта 25-летний бельй медведь по прозвищу Антон съел сумку одного из посетителей. В результате инциидента животное скончалось.

Семантична компресія проявляється в перенесенні інформації на імпліцитний рівень висловлювання, в результаті чого передана ним інформація перевищує його пряме значення, виражене мовними засобами.

\section{3. Проблеми перекладу стислого тексту}

Специфічні особливості перекладу СТ зумовлюються, по-перше, тим, що його важливе призначення полягає в тому, щоб зацікавити читача, привернути його увагу до створеного матеріалу. По-друге, СТ має в короткій формі викласти повідомлення або виділити найбільш важливі факти. По-третє, СТ має переконати читача, вселити йому основну ідею опублікованого матеріалу. У цьому підрозділі ми розглянемо проблеми перекладу СТ на двох прикладах: особливості перекладу заголовка 3 англійської мови та перекладу коротких віршованих творів з російської мови англійською.

Специфічна побудова англійських газетних заголовків служить різним цілям; щоб вони змусили читача зацікавитися заміткою i забезпечити компресію інформації, тож під час перекладу перекладач має подолати деякі особливо важливі труднощі і проблеми, які ми розглянемо далі. Під час читання всього тексту в цьому разі на правильне розуміння може наштовхнути контекст, адже у випадку заголовка ми його не маємо, наприклад: 
"Violent stellar collision near early solar system created actinides". Бурхливе зіткнення біля ранньої сонячної системи створило актиніди.

$\mathrm{y}$ цьому прикладі прикметник violent, який означає «насильницький, запеклий, небезпечний, жорстокий», не можна перекласти за цими варіантами, позаяк їх неможливо застосувати до зоряного зіткнення. Тому для збереження адекватності перекладу ми обрали значення, яке сумісне 3 основними значеннями, керуючись навколишнім текстом i контекстом самої статті $\mathrm{i}$, виходячи iз загального змісту думки, укладеної в реченні і тексті.

"Floppiness scale untangles knotted molecules". Шкала гнучкості розилутує вузлові молекули.

Означення, виражене дієприкметником минулого часу (Past Participle), можна перекласти як «заплутаний, зав'язаний», але для правильного перекладу перекладачу необхідно володіти базовими знаннями тематики чи перевірити наявність цього терміна в словнику. Після пошуку терміна knotted molecule можна знайти його еквівалент в українській мові - вузлові молекули.

Крім того, в науковій англійській мові є визначена категорія слів, яка також являє значні труднощі під час перекладу, - це слова, схожі в обох мовах за написанням, але такі, що відрізняються за значенням (так звані «хибні друзі перекладача»). Наприклад:

"How Accurate Are Fitness Trackers?". Наскільки точні фітнестрекери?

Останній приклад міжмовного омоніму у заголовку подано в New York Times. Прикметник accurate в словнику перекладається як точний, а не акуратний в значенні «акуратний» (tidy). Зі змісту заголовка випливає, що фітнес-трекер не може бути акуратним, тож треба бути уважним, щоб не скоїти таку помилку.

Наведемо ще декілька яскравих прикладів. “The Known Unknowns of leptin in pregnancy”. Невідомі факти про лептин під час вагітності.

“The Door of Hope”. У цьому разі у статті йдеться про нові можливості щодо лікування раку, тож доцільно буде перекласти назву як Двері надії: нові досягнення у лікуванні раку.

“Heart to Heart”. Наукова стаття присвячена питанням трансплантації серця, тож вважаємо доречним пояснити це в перекладі: Від серия до серия: проблеми трансплантації.

Безумовним джерелом характерних помилок під час відтворення назв наукових та науково-популярних статей $є$ досить часте вживання в них скорочень. Кожне відкриття, кожне нове досягнення приносить нові і нові скорочення, які потрібно розшифрувати і запропонувати адекватний аналог в рідній мові. Деякі скорочення зрозумілі науковцям 
різних спеціальностей, деякі вживаються лише у вузькій галузі. Розглянемо приклад:

"For the Third Time, W.H.O. Declines to Declare the Ebola Outbreak an Emergency". Втретє ВООЗ відмовляється оголосити надзвичайну ситуацію щзодо Еболи.

Багато англійських і американських скорочень мають еквіваленти в українській мові, які і слід використовувати для перекладу заголовків, причому необхідно мати на увазі, що ці еквіваленти є скороченням української назви відповідної організації, що і $є$ в цьому прикладі. W.H.O. - World Health Organization має еквівалентний український варіант ВОО3 (Всесвітня організація охорони здоров’я).

"Laurus Labs completes USFDA inspection of Vizag API facilities". Laurus Labs завериує інспекиію УПМ США об' сктів Vizag API.

У цьому прикладі використано два скорочення - USFDA і API. $U S F D A$ - Управління продовольства і медикаментів Сполучених Штатів Америки, який складається 3 двох частин US+FDA. FDA має відповідний еквівалент в українській мові - УПМ (Управління продовольства і медикаментів), так само, як і назва країни, про яку йдеться, - США. Тож ми об'єднали два скорочення, щоб утворити нове скорочення і закрити прогалину. Друге скорочення API (Application Programming Interface) не має українського еквіваленту і $є$ терміном, який залишається незмінним під час перекладу, так само, як наприклад USB.

Ще одним складним для перекладу жанровим стислим утворенням $€$ так звані віршики-перашки - зразок іронічної поезії з порушенням усіх мовних норм. Значна кількість віршиків-перашків різною мірою вдало перекладено англійською мовою (переклади Антона Василевського). Наведемо один із прикладів:

Глеб переехал в Подмосковье, / Не в то, которое вокруг, / А в настоящее, под землю, / И скоро тоже стал землёй.

Gleb one day moved to downtown. / Not that, which is in city's heart. I Exactly down underground. I And soon became himself a glebe.

У цьому випадку вдало переведено текст із використанням морфологічного рівня, оскільки в двох мовах збіглася багатозначність морфеми down і під-, які можуть бути зрозумілі як «навколо» $\mathrm{i}$ «внизу» i як «центр міста». У цьому разі рівень стиснення в оригіналі i перекладі збігається.

У прикладі Щас вместо сыра в мышеловки / Кладут краситель консервант, / Стабилизатор эмульгатор / И ароматизатор сыр. / In mousetraps instead of cheese now. / They put some dye preservative, / Emulsifier, stabilizer, / And cheesy flavored substitute 
Стиснення на фонемно-графемному рівні щзас не знайшло відображення в перекладі, так само як і пропуск підлягає в оригіналі.

У прикладі Писал про битвы и закатьы. / Писал про юношей и дев. / Издали, выплатили деньги. / Купил коньяк, нажрался, сплю. / I wrote about dawns and battles. / About maidens and young men. / I publicated book, got payment. / Bought cognac. Drunk. Knocked out. Sleep у першому i другому реченні перекладу не еліптовано підмет, однак сегментований характер оригінального тексту вдало відображений в останньому рядку.

Цікавий приклад компенсації спостерігаємо в такому перекладі: Моя фамилия Есенин. / Я здесь повеситься хочу. / Как номеров свободных нету? / Я максимум на полчаса. / My name is Ernst. Surname is Toller. / I wanna here hang myself. / What do you mean all rooms are busy? / I need half-hour. No more.

Німецький поет Ернст Толлер, про якого йдеться у перекладі, $є$ однією 3 найяскравіших постатей експресіонізму. У 1939 році в Мадриді в готелі «Мейфлауер» Толлера виявили повішеним. Ця трагічна подія нагадує про смерть Сергія Єсеніна, що дало підставу перекладачеві компенсувати ці імена в своєму чорному гуморі.

Отже, різноманітні способи створення стислого тексту застосовні в усіх стилях, включаючи художній. Переклади демонструють широкі можливості знаходження відповідностей досягнення компресії на різних рівнях побудови тексту.

\section{ВИСНОВКИ}

Сучасна палітра текстового втілення будь-якої мови була б неповною без такого корисного мовного твору, як стислий текст. Цей тип тексту дає змогу оптимізувати процес як усної, так і письмової комунікації в усіх сучасних дискурсах.

Стислий текст - це повідомлення, об'єктивоване подібно до будь-якого іншого тексту в письмовій формі, побудоване шляхом скорочення повного тексту або спочатку створене як коротке, призначене за необхідності для подальшого розгортання в більший текст. У статті розглянуто такі види стислих текстів, як первинний та вторинний, нормовано або форсовано стислий та ін.

У XXI столітті номенклатура стислих текстів зазнала значних змін. Пішли в небуття такі відомі твори, як телеграми, натомість наше життя вже неможливо уявити без СМС-повідомлень. У статті розглянуто також інші популярні як традиційні, так і нові жанри СТ у науковотехнічному, офіційно-діловому, газетно-публіцистичному та художньому стилях. 
Усі стислі тексти вирізняються інтенсивним застосуванням різних засобів досягнення компресії на графемному, граматичному та лексикосемантичному рівнях мови. Що стосується першого, то тут основна роль належить буквеним скороченням, розділовим знакам, особливому розташуванню матеріалу, на другому поширення набувають перевага використання іменників та дієслів за рахунок допоміжних частин мови, простих речень i різних видів еліпсису, третій представлений специфічними абревіатурами та підвищеною роллю імпліцитного рівня повідомлення.

Лінгвальні особливості стислих текстів призводять до виникнення додаткових проблем для перекладачів, оскільки вони мають брати до уваги не тільки зміст, але й стислу форму повідомлення, яку треба зберегти, аби не втратити самий сенс такого явища, як стислий текст.

\section{АНОТАЦІЯ}

У статті дається визначення стислого тексту як особливого лінгвістичного феномена. Запропонована класифікація стислих текстів. Підгрунтям їх створення є мовна компресія, яка може виявлятися на всіх рівнях мови. На графемному рівні стиснення тексту здійснюється за рахунок різноманітних графічних скорочень, особливого використання пунктуаційних знаків, шрифтів та поділу на абзаци. На граматичному рівні спільним для російської та англійської мов $\epsilon$ зміна співвідношення частин мови та спрощення граматичних категорій. В англійській мові специфічним є вилучення допоміжних слів, зокрема, у заголовках. На лексико-семантичному рівні звертають на себе увагу коротші синоніми, нова інтернет-лексика, перенесення інформації на імпліцитний рівень висловлювання. Проблеми перекладу СТ та деякі шляхи їх вирішення продемонстровано на прикладах перекладу заголовків та коротких поетичних творів.

\section{ЛIТЕРАТУРА}

1. Ахманова О.С. Словарь лингвистических терминов. Москва : УРСС : Едиториал УРСС, 2004. $571 \mathrm{c.}$

2. Леонтьев А.А. Высказывание как предмет лингвистики и теории коммуникации. Синтаксис текста. Москва, 1979. С. 18-36.

3. Мальченко Л.А. К вопросу о компрессии и избыточности разговорной речи. Теория и практика лингвистического описания речи. Горький, 1976. Вып. 7. С. 37-39.

4. Панченко Е.И. Лингвистика сжатого текста (на материале современного русского языка) : дисс. ... д-ра филол. н. : 10.02 .02 «Русский язык». Днепропетровск, 1998. 380 с. 
5. Риш Г.А. К понятию компрессии в языке. Труды Самарского университета. Вопросы семантики индоевропейских языков. 1973. Вып. 24. С. 36-48.

6. Тріщук О. Робота редактора над рухомим рядком. Вісник Книжкової палати. 2016. № 2. С. 7-10.

7. Jespersen O. A Modern English Grammar on Historical Principles. Copenhagen, 1942. 1120 p. DOI: https://doi.org/10.4324/9780203715963.

\section{Information about the authors:}

Panchenko O. I.,

Doctor of Philological Sciences, Full Professor, Head of the Department of Translation and Linguistic Training of Foreigners Oles Honchar Dnipro National University 72, Gagarin Avenue, Dnipro, 49010, Ukraine

Shevchyk K. Yu., Candidate of Philological Sciences, Associate Professor at the Department of Translation and Linguistic Training of Foreigners Oles Honchar Dnipro National University 72, Gagarin Avenue, Dnipro, 49010, Ukraine 